\title{
Unusual cause of hyponatremia in a young patient with varicella zoster infection: a case report
}

\begin{abstract}
Hyponatremia is one of the more common electrolyte abnormalities in clinical medicine Some sources estimate that the number of patients who experience sodium levels of $<135 \mathrm{meq} / \mathrm{L}$ can be as high as $30 \%$ of all hospitalized patients. SIADH is the usual cause of Hyponatremia in patients with Varicella Zoster infection. Severe hyponatremia can cause substantial morbidity and mortality. The most common manifestations are CNS-related and include lethargy, confusion, disorientation and agitation. Serious manifestations include seizures, hypoxia and coma. We present here a report of an adult patient who presented with Varicella Zoster infection with seizures, agitation and unresponsiveness due to hyponatremia. Patient was on homeopathic medications and salt free diet since 3 days and was advised to take only free water to prevent exacerbations of skin lesions.
\end{abstract}

Volume 7 Issue 5 - 2019

Sandeep Kantor, Juhi Chandwani, Seif Al Abri, Antara Gokhale, Sadanandan Prakash

Department of Intensive Care, The Royal Hospital, Oman

Correspondence: Juhi Chandwani, Department of Intensive Care, The Royal Hospital, Al Ghubrah Street, I I I Muscat, Oman, Email drjuhi@yahoo.com

Received: August 13, 2019 | Published: September 05, 2019

Keywords: varicella zoster, hyponatremia, homeopathy

\section{Introduction}

Hyponatremia, defined as serum sodium below $135 \mathrm{mEq} / \mathrm{L}$, is one of the most frequently encountered electrolyte disorders in critically ill patients. ${ }^{1}$ Patients at risk include septic patients, postoperative patients, older patients on thiazide diuretics, patients with malignant or psychiatric illness, and endurance athletes. A serum sodium concentration $<100 \mathrm{mEq} / \mathrm{l}$, carries a high risk of brain damage due to seizure activity. There is concern about injury to the brain for rapid and over correction of hyponatremia. We present here a patient who presented with Varicella Zoster infection and symptomatic hyponatremia due to volitional intake of free water as per advice of homeopathy physician. Hypertonic saline, fluid restriction and close monitoring in the intensive care unit led to complete recovery of the patient with no residual neurological deficit.

\section{Case report}

A 42-yr old man, with no known comorbidities, presented with fever, convulsions and vesicular eruptions over thorax, extremities, head \& neck due to Varicella Zoster infection of three days duration. He was treated at home by a family homeopathy physician who prescribed alternative medications and salt free diet and was also advised to take only free water to prevent exacerbation of skin lesions and irritability. In the emergency room, patient was convulsing, unresponsive, agitated and combative with Glasgow Coma Scale (GCS) of 7/15 and had oral bleed due to tongue bite. He was sedated, intubated and ventilated and remained stable hemodynamically. Initial blood investigations revealed serum sodium concentration of $113 \mathrm{mEq} / 1$ with normal renal and liver functions. Other biochemical parameters were as shown in Table 1. Cortisol and thyroid levels were within normal limits. Septic work up was unremarkable.

Table I Biochemistry and urine laboratory test results

\begin{tabular}{lllllllll}
\hline Test & Unit & On admission & 6hrs after & $\mathbf{1 2}$ hrs after & Day 2 & Day 3 & Day 4 & Day 18 \\
\hline Serum Sodium & $\mathrm{mmol} / \mathrm{L}$ & 113 & 118 & 121 & 124 & 128 & 132 & 137 \\
Serum Chloride & $\mathrm{mmol} / \mathrm{L}$ & 79 & 92 & 94 & 99 & 100 & 101 & 104 \\
Serum K & $\mathrm{mmol} / \mathrm{L}$ & 4.3 & 3.6 & 3.8 & 3.9 & 4 & 4.4 & 4.6 \\
Serum Osmolality & $\mathrm{mOsmol} / \mathrm{kg}$ & 236 & & & & & & \\
Urine Na & $\mathrm{mmol} / \mathrm{L}$ & 59 & 80 & & & & & \\
Urine Osmolality & $\mathrm{mOsmol} / \mathrm{kg}$ & 608 & & & & &
\end{tabular}

$\mathrm{CT}$ of the head showed no evidence of cerebral edema, meningeal enhancement, stroke or space occupying lesions. Cerebrospinal fluid studies were normal. He was managed as symptomatic euvolemic hyponatremia, due to SIADH aggravated by increased free water ingestion and salt restriction. EEG showed nonspecific generalized slowing with no epileptic discharges. The patient received 2 doses of $150 \mathrm{mls} 3 \%$ hypertonic saline in first 4 hours until his sodium reached
$120 \mathrm{mEq} / \mathrm{l}$, followed by normal saline infusion according to his calculated fluid deficit subsequently. Rate of sodium correction was meticulously monitored at 1, 6 and 12 hours. He was simultaneously treated with antiviral (Acyclovir) and antibiotics along with supportive management. He was successfully weaned off ventilator within 48 hours once his sodium normalized with no residual neurological deficit and was discharged home after 4 days of hospitalization. Serum 
sodium levels on the day of discharge were $132 \mathrm{mEq} / \mathrm{L}$ with Glasgow Outcome scale of 1. Follow up two weeks later was unremarkable, with serum sodium levels of $137 \mathrm{mEq} / \mathrm{L}$ and complete recovery from chicken pox with some residual scars.

\section{Discussion}

Hyponatremia can be due to various causes (Table 2). SIADH is a known entity in patients with viral infections including Varicella Zoster which could have been one of the factors in our patient as he was euvolemic with urine Osmolality more than that of serum. ${ }^{2}$ However, hyponatremia in our patient was also exacerbated due to excess ingestion of salt free fluids and salt restriction leading to severe

Table 2 Causes and characteristics of hyponatraemia* symptomatic hyponatremia, on the advice of homeopathic physician. The best way of symptomatic hyponatremia is to administer hypertonic saline solution. This was achieved promptly in our patient by giving hypertonic saline $150 \mathrm{mls}$, total 2 doses in 6 hours, along with fluid restriction with regular monitoring of serum sodium at 1,6 and 12 hours without overcorrecting it which led to his complete neurological recovery. Guidelines for managing hyponatremia are based mostly on retrospective studies and expert opinion, and recommendation is to promptly increase serum sodium concentration (by at least $4-6 \mathrm{mEq} / \mathrm{L}$ ) without overcorrecting it (i.e. $>10 \mathrm{mEq} / \mathrm{l}$ in 24 hours and/or $18 \mathrm{mEq} / \mathrm{L}$ in 48 hours) ${ }^{3,4}$ Risk of rapid correction of serum sodium $(>10 \mathrm{mEq} / 1$ in 24 hours or $18 \mathrm{mEq}$ in 48 hours) in acute Hyponatremia includes Osmotic Demyelination syndrome which has worse prognosis. ${ }^{5}$

\begin{tabular}{|c|c|c|c|}
\hline \multicolumn{3}{|c|}{ Volume of extracellular fluid } & \multirow[b]{2}{*}{ Expanded } \\
\hline Variable & Contracted & Normal or near normal & \\
\hline Causes & $\begin{array}{l}\text { Diarrhea; vomiting; excessive } \\
\text { sweating; poor water intake; } \\
\text { diuretic use }\end{array}$ & $\begin{array}{l}\text { Syndrome of inappropriate secretion of } \\
\text { antidiuretic hormone; hypothyroidism; adrenal } \\
\text { insufficiency }\end{array}$ & $\begin{array}{l}\text { Congestive heart failure; } \\
\text { cirrhotic liver disease; } \\
\text { nephrotic syndrome }\end{array}$ \\
\hline Serum osmolality & Low & Low & Low \\
\hline $\begin{array}{l}\text { Urine osmolality } \\
(\mathrm{mOsm} / \mathrm{L})^{\dagger}\end{array}$ & $>500$ & $>100$ & $>100$ \\
\hline Urine volume & Usually decreased & Varies with intake & Usually decreased \\
\hline $\begin{array}{l}\text { Urine sodium } \\
\text { concentration } \\
(\mathrm{mmol} / \mathrm{L})\end{array}$ & $<20^{\ddagger}$ & $>40$ & $<20^{\ddagger}$ \\
\hline $\begin{array}{l}\text { Response to } \\
0.9 \% \text { saline } \\
\text { infusion }\end{array}$ & $\begin{array}{l}\text { Clinical and biochemical } \\
\text { improvement }\end{array}$ & No change or worsening of hyponatraemia & $\begin{array}{l}\text { Little change in hyponataemia, } \\
\text { worsening of edema }\end{array}$ \\
\hline
\end{tabular}

*For simplicity, conditions such as cerebral salt wasting and "reset osmostat" have been omitted.

tValues less than 100 imply an appropriate pituitary and renal response to hyponatremia, as would be expected with psychogenic polydipsia. The variability in urine osmolality results in low sensitivity and specificity for causes of hyponatremia in which the osmolality is greater than $100 \mathrm{mOsm} / \mathrm{L}$.

¥May be greater than 20 with diuretic use.

The findings of currently available Cochrane reviews of studies of homeopathy do not show that homeopathic medicines have effects beyond placebo. ${ }^{6,7}$ The treatment of hyponatremia is determined by 3 major factors: severity of hyponatremia, that is, the presence or absence of severe CNS symptoms such as lethargy, delirium, seizure, and coma; onset of hyponatremia: acute (within 48 hours) or chronic ( $>48$ hours); and volume status. ${ }^{8}$ The biggest challenge of treating symptomatic hyponatremia is how to prescribe saline therapy and maintain the correction rate in the target range. It cannot be overstated that frequent measurements of the serum sodium must be performed in concert with whichever calculations are used; as clinical estimates of TBW are rather crude. Nguyen and Kurtz reviewed potential errors with simplified formulae. If the rate of correction is too fast or too slow, we may need to alter the infusion rate and/or administer furosemide dose may be necessary. ${ }^{9}$

In our case we followed the protocol based on FWE along with frequent monitoring of serum sodium and other electrolytes. Overcorrection of hyponatremia could be managed by administration of desmopressin along with careful administration of fluids to keep up with unwanted urinary water losses. This is especially common in patients who have chronic hyponatremia, or whose initial sodium concentration is $\leq 105 \mathrm{mEq} / \mathrm{L}$, patients with hypokalemia, alcoholism, malnutrition and those with liver disease. ${ }^{10}$ Recently, conivaptan, a V1A/V2-receptor antagonist, was approved for treating hospitalized patients with euvolemic Hyponatremia. However, the risk of rapid correction is still present; therefore, frequent checks of serum sodium are needed. ${ }^{11}$ Patient education leaflets and sites never mention about possibility of hyponatremia in Chicken pox patients leave alone risk of hyponatremia with salt restricted fluids as was seen in our patient. This could be one area which we need to look at which could prevent complications in a seemingly benign Varicella Zoster diagnosed patient who otherwise have a god recovery. ${ }^{12}$

\section{Funding details}

None.

\section{Acknowledgments}

None.

\section{Conflicts of interest}

Authors declare that there is no conflict of interest. 


\section{References}

1. Padhi R, Panda BN, Jagati S, et al. Hyponatremia in critically ill patients. Indian J Crit Care Med. 2014;18(2):83-87.

2. Wang CC, Shiang JC, Chen JT, et al. Syndrome of Inappropriate Secretion of Antidiuretic Hormone Associated with Localized Herpes Zoster Ophthalmicus. J Gen Intern Med. 2011;26(2):216-220.

3. Sterns RH, Nigwekar SU, Hix JK. The treatment of hyponatraemia Semin Nephrol. 2009;29(3):282-299.

4. Spasovski G, Vanholder R, Allolio B, et al. Clinical practice guideline on diagnosis and treatment of hyponatraemia. Eur $J$ Endocrinol. 2014;170(3):G1-47.

5. Sterns RH, Kevin JK, Silver S. Treating Profound Hyponatraemia: A Strategy for Controlled Correction. Am J Kidney Dis. 2010;56(4):774779.

6. Dantas F, Rampes H. Do homeopathic medicines provoke adverse effects? A systematic review. Br Homeopath J. 2000;89(Suppl.1):S35-S38.
7. Ernst E. Homeopathy: what does the "best" evidence tell us? Med J Aust 2010;192(8):458-460.

8. Sterns RH, Hix JK. Overcorrection of hyponatraemia is a medical emergency. Kidney Int. 2009;76(6):587-589.

9. Nguyen MK, Kurtz I. Analysis of current formulas for treatment of dysnatraemia. Clin Exp Nephrol. 2004;8(1):12-16.

10. Sood L, Stern RH, Hix JK, et al. Hypertonic Saline and Desmopressin: A simple strategy for safe correction of severe hyponatremia. Am J Kidney Dis. 2013;61(4):571-578.

11. Aditya S, Rattan A. Vaptans: A new option in the management of hyponatremia. Int J Appl Basic Med Res. 2012;2(2):77-83.

12. Chickenpox-Symptoms \& causes. USA: Mayoclinic. 